\title{
ANALISIS PRAKTIK ETIKA BISNIS SYARIAH (STUDI KASUS PASAR LEUWILIANG)
}

\author{
Ira Puspitasari \\ Program Studi Ekonomi Syariah, Fakultas Agama Islam, Universitas Ibn Khaldun Bogor \\ Jl. K.H. Soleh Iskandar Km. 2 Kedung Badak, Tanah Sareal, Bogor, Jawa Barat \\ Irapuspita15@outlook.com
}

\begin{abstract}
Abstrak
Penelitian ini bertujuan untuk mengeatui bagaimana etika bisnis pedagang secara islam, bagaimana praktik etika bisnis pedagang di pasar leuwiliang dan untuk mengetahui etika bisnis syariah di kalangan pedagang muslim di pasar leuwiliang. Metode pengumpulan data dilakukan dengan menggunakan metode kualitatif. informan penelitian ini berjumlah 25 orang. Data tersebut diperoleh dari hasil wawancara dengan pedagang di pasar leuwiliang. Hasil dari penelitian tersebut ditemukan bahwa belum sepenuhnya para pedagang di Pasar Leuwiliang faham mengenai etika bisnis syariah, namun dari jawaban yang mereka berikan mengenai menjaga kehalalan produk serta bagaimana menjaga kepercayaan pelanggan sudah bisa dikatakan bahwa mereka sedikitnya telah menerapkan etika bisnis secara syariah.
\end{abstract}

Kata Kunci: Etika Islam, Etika Bisnis, Etika Bisnis Islam

\begin{abstract}
This study aims to understand how business ethics of traders in Islam, how to practice business ethics of traders in the market of Leuwiliang and to know Islamic business ethics among Muslim traders in the market of Leuwiliang. The method of data collection is done using qualitative methods. The research informants were 25 people. The data is obtained from the results of interviews with traders in the market Leuwiliang. The results of the study found that not all traders in Pasar Leuwiliang understood about sharia business ethics, but from the answers they gave regarding maintaining product halalness and how to maintain customer trust it could be said that they had at least implemented business ethics in sharia.
\end{abstract}

Keyword : Islamic Ethics, Business Ethics, Sharia Business Ethics.

\section{PENDAHULUAN}

Berdagang menjadi suatu pilihan yang sangat sederhana bagi masyarakat untuk mencari nafkah. Dimulai dari modal yang relartif kecil disertai keahlian yang cukup sudah bisa berdagang sehingga dari hasil berdagang kebutuhan mereka dapat terpenuhi. (Azizaturrohmah \& Mawardi,
Berdasarkan data statistik yang dilakukan oleh BPS (Badan Pusat Statistik) pada sesnsus penduduk tahun 2010, tercatat $87,2 \%$ (207, 2 jiwa) dari 236, 4 juta jiwa masyarakat beragama Islam. Oleh karena itu, masyarakat beragama Islam tentunya memiliki peran yang sangat penting dalamperkembangan perekonomian negara. 2015)

Received: 2018-10-11 | Reviced: 2019-02-10 | Accepted: 2019-02-13

Indexed : DOAJ, Garuda, Crossref, Google Scholar | DOI: https://doi.org/10.29313/amwaluna.v3i1.4125 
Disisi lain, pelaku ekonomi dalam sektor mikro yaitu konsumen, produsen, dan government dipertemukan dalam mekanisme pasar dimana terjadinya interaksi sosial antara permintaan dan penawaran atau biasa disebut perdagangan yang akan menentukan tingkat harga tertentu. Dengan kata lain, pelaku ekonomi dalam sektor mikro tersebut ikut andil dalam perkembangan perekonomian negara. (Suprayitno, 2008) (Bayuni \& Srisusilawati, 2018)

Dalam ruang lingkup perdagangan, seorang pedagang mengejar keuntungan merupakan suatu hal yang sangat wajar, akan tetapi mencapai keuntungan tersebut perlu memperhatikan pihak lain. Salah satu bentuk perhatian tersebut yaitu dengan berperilaku etis dalam berdagang demi kelangsungan hidup pedagang itu sendiri. Perilaku etis seorang pedagang dapat berupa menerapkan nilai-nilai moral dalam setiap aktivitasnya jika dilihat dari perspektif jangka panjang. Perilaku yang tidak etis dapat merugikan dirinya sendiri karena di kemudian hari halhal yang tidak diinginkan bisa saja terjadi jika seorang pedagang tidak menerapkan nilainilai moral dalam setiap aktivitasnya. (Amalia, 2014)

Perilaku etis dengan menerapkan nilai-nilai moral dalam aktivitas berdagang telah ditetapkan dalam ajaran Islam dimana Islam memberi garis pemisah atau suatu batasan antara hal-hal yang boleh dilakukan dan hal-hal yang tidak boleh dilakukan, seperti menghalalkan segala cara berupakecurangan, penipuan, riba, sumpah palsu, menyuap, dan perbuatan-perbuatan yang tidak boleh lainnya. Garis pemisah atau suatu batasan inilah yang biasa dikenal dengan istilah etika (Amalia, 2014)

Islam mengatur semua kegiatan manusia termasuk dalam melakukan muamalah dengan memberikan batasan apa saja yang boleh dilakukan (Halal) dan apa saja yang tidak diperbolehkan (Haram). (Syihabuddin, 2017) Dalam bisnis Islam, bisnis yang dilakukan harus berlandaskan sesuai syaria'ah atau Islamic law. (Juliyani, 2016) (Gunawan, 016) Semua hukum dan aturan yang ada dilakukan untuk menjaga pebisnis agar mendapatkan rejeki yang halal dan di ridhai oleh Allah SWT serta terwujudnya kesejahteraan distribusi yang merata. Maka etika atau aturan tentang bisnis Islam memiliki peran yang penting juga dalam bisnis berbasis syari'ah. (Saifullah, 2011)

Penelitian selanjutnya dilakukan oleh (Saman, 2010) di UIN Syarif Hidayatullah Jakarta yang berjudul "Persaingan Industri PT Pancanata Centralindo (Perspektif Etika Bisnis dalam Islam)". Penelitian ini bersifat kualitatif deskriptif yang bertujuan untuk mengetahui persaingan industri dari PT Pancanta Centralindo dari segi etika bisnis Islam. 
Perbedaan penelitian yang dilakukan oleh penulis dengan penelitian yang telah dijelaskan diatas terletak pada fokus penelitian. Fokus penelitian yang dilakukan oleh penulis adalah untuk mengetahui praktik etika bisnis pedagang yang berlangsung di Pasar Leuwiliang.

$$
\text { Hasil penelitian tersebut }
$$
menunjukkan bahwa etika atau perilaku yang ditanamkan PT Pancanata Centralindo terhadap karyawannya tidak sepenuhnya dilaksanakan, ini terbukti masih ada karyawan yang menjual harga barang berbeda dengan harga yang telah diberlakukan oleh pemilik perusahaan, dan adanya kesenjangan sosial antara pembeli dalam jumlah besar dengan pembeli dalam jumlah kecil dalam hal fasilitas layanan. Barang yang dipesan tidak sesuai dengan yang diinginkan dengan ukuran yang tidak sesuai dan barang yang dipesan lama sampainya dan ada barang yang rusak atau cacat. Adanya ketidakpuasan terhadap barang yang disama-ratakan untuk semua ukuran.

Terdapat juga penelitian yang dilakukan oleh (Amalia, 2014) di UIN Syarif Hidayatullah Jakarta dalam penelitiannya yang berjudul "Implementasi Etika Bisnis Islam Pada Pedagang Di Bazzar Madinah Depok". Penelitian ini bertujuan untuk mengetahui bagaimana implementasi etika bisnis Islam bagi para pedagang di
Bazzar Madinah Depok dengan menggunakan jenis penelitian studi kasus dan metode survei. Perbedaan penelitian yang dilakukan oleh penulis dengan penelitian yang telah dijelaskan diatas terletak pada hasil penelitian. Hasil penelitian yang di inginkan oleh penulis hanya terletak pada etika bisnisnya saja.

Hasil penelitiannya adalah dalam kegiatan produksi, harga, manajemen, dan para pedagang sebagian besar sudah menjalankan usahanya sesuai syariat Islam.

$$
\text { Penelitian lainnya oleh }
$$
(Firmansyah, 2013) di UIN Sunan Kalijaga Yogyakarta dalam penelitiannya berjudul "Praktik Etika Bisnis Islam (Studi Kasus Pada Toko Santri Syari'ah Surakarta)". Penelitian ini bersifat kualitatif dengan pengumpulan data melalui wawancara, observasi, dan dokumentasi. Penelitian ini bertujuan untuk mengetahui nilai-nilai etika bisnis Islam yang dilakukan oleh Toko Santri Syarieah Surakarta. Kesimpulan dari penelitian ini adalah bahwa praktik etika bisnis yang dilakukan di Toko Santri dalam hal permodalan serta pengaruh toko santri terhadap lingkungan sosial sekitarnya telah sesuai dengan hukum Islam. Sedangkan masalah hubungan dengan SDM dalam hal ini tentang pemenuhan hak pekerja belum dijalankan sesuai aturan Islam, sebagai contohnya yaitu: pekerja tidak diberikan ilmu atau pengetahuan tentang etika bisnis 
Islam. Perbedaan penelitian yang dilakukan oleh penulis dengan penelitian yang telah dijelaskan diatas terletak pada lokasi penelitian dan objek yang di teliti, jika penelitian sebelumnya melakukan penelitian nilai-nilai etika bisnis Islam yang dilakukan oleh Toko Santri Syarieah Surakarta di UKM, sedangkan penelitian yang akan penulis lakukan berlokasi di Pasar Leuwiliang.

\section{METODE PENELITIAN}

\section{Jenis Penelitian}

penelitian ini menggunakan pendekatan kualitatif yakni penelitian yang berusaha untuk menuturkan pemecahan masalah yang ada berdasarkan data-data dengan cara menyajikan data, menganalisis data dan menginterprentasikanya.

Jenis penelitian ini menggunakan metode kualitatif.Metode penelitian kualitatif adalah metode penelitian yang digunakan untuk meneliti pada kondisi obyek yang alamiah, (sebagai lawanya adalah eksperimen) dimana peneliti adalah sebagai isntrumen kunci, teknik pengumpulan data dilakukan secara triangulasi (gabungan), analisis data bersifat induktif, dan hasil penelitian lebih menekankan makna dari pada generalisasi.

Jenis penelitian ini adalah kualitatif. Penelitian ini bermaksud mendeskripsikan tentang Penelitian kualitatf bertujuan untuk menjelaskan fenomena dengan sedalam- dalamnya. Penelitian ini tidak mengutamakan besarnya populasi atau sampling. Jika data yang terkumpul sudah mendalam dan bisa menejelaskan fenomena yang diteliti, maka tidak perlu menceri sampling lainya. Penelitian kualitatif lebih menekankan pada persoalan kedalaman atau kualitas data.

Teknik pengumpulan data penelitian ini menggunakan dua macam sumber data yaitu data primer dan data sekunder. Data primer adalah data yang diperoleh secara langsung pada obyek yang bersangkutan, data primer dalam penelitian ini diperoleh melalui wawancara peniliti yang akan ditanyakan kepada responden yaitu pedagang Pasar Leuwiliang.

Data sekunder adalah data yang diperoleh secara tidak langsung (melainkan dari pihak lain). Data sekunder dalam penelitian ini diperoleh dari studi pustaka yang mendukung penulisan penelitian, serta diperoleh dari buku-buku, jurnal, skripsi, internet dan berbagai literatur yang relavan dengan penelitian ini.

Setelah dilakukan penelitian dan pengumpulan data dilapangan melalui wawancara dengan responden, maka diperoleh berbagai data dari responden terkait dengan Analisis praktik etika bisnis syariah di Pasar Leuwiliang. Adapun tempat dan waktu penelitian ini dilakukan di Pasar Leuwiliang, Bogor, Jawa Barat. 


\section{TEKNIK PENGUMPULAN DATA}

Teknik pengumpulan data penelitian ini menggunakan dua macam sumber data yaitu data primer dan data sekunder.

Data primer adalah data yang diperoleh secara langsung pada obyek yang bersangkutan, data primer dalam penelitian ini diperoleh melalui wawancara peniliti yang ditanyakan kepada responden yaitu pedagang Pasar Leuwiliang.

Data sekunder adalah data yang diperoleh secara tidak langsung (melainkan dari pihak lain). Data sekunder dalam penelitian ini diperoleh dari studi pustaka yang mendukung penulisan penelitian, serta diperoleh dari buku-buku, jurnal, skripsi, internet dan berbagai literatur yang relavan dengan penelitian ini.

\section{PEMBAHASAN}

Etika Islam (bahasa Arab: أخلاق atau "Adab dan Akhlak Islamiyah" adalahetika dan moral yang dianjurkan di dalam ajaran Islam yang tercantum di dalam Al-Quran dan Sunnah, dengan mengikuti contoh dari teladan Nabi Muhammad, yang didalam akidah Islamiyah dinyatakan sebagai manusia yang paling sempurna akhlaknya. (Mabarroh, 2016)

Dalam hubungan manusia dengan Allah SWT dapat dikembangkan melalui etika Tauhid dengan mengikuti segala perintahnya dan menjauhi segala larangannya sebagaimana dalam berperilaku baik dari perkataan maupun perbuatan yang dilakukan secara langsung maupun tidak langsung. Sedangkan dalam hubungan manusia dengan sesama makhluk dapat dikembangkan melalui sikap etis yang baik menurut akal sehat dan tidak keluar dari jalur norma agama serta dapat dipertanggung jawabkan.

Etika (akhlaq) merupakan suatu sifat yang tertanam dalam jiwa (manusia), yang dapat melahirkan suatu perbuatan yang mudah dilakukan tanpa melalui maksud untuk memikirkannya (lebih lama). (Baidowi, 2016) Maka jika sifat tersebut melahirkan suatu tindakan yang terpuji menurut ketentuan akal dan norma agama, dinamakan akhlak yang baik. Akan tetapi manakala ia melahirkan tindakan yang jahat, maka dinamakan akhlak yang buruk.. Akhlak yang baik dan buruk tersebut telah termaktub dalam Al-Qurean dan Hadits yang menjadi dasar bagi etika Islam . (Rosiyana, Arifin, \& sunarti, 017)

Titik sentral etika Islam merupakan penentuan kebebasan manusia untuk bertingkah laku dan bertanggungjawab karena kepercayaan terhadap kemahakuasaan Allah Hanya saja kebebasan itu tidaklah mutlak, dalam arti kebebasan yang terbatas. Jika sekiranya manusia memiliki kebebasan mutlak, maka berarti manusia menyaingi 
kemahakuasaan Allah selaku pencipta (Khalik) semua makhluk, tanpa kecuali adalah manusia itu sendiri. Dalam etika Islam, manusia adalah pusat ciptaan Allah .

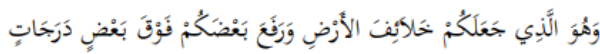

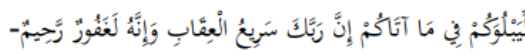

"Dan Dia-lah yang Menjadikan kamu sebagai khalifahkhalifah di bumi dan Dia Mengangkat (derajat) sebagian kamu di atas yang lain, untuk mengujimu atas (karunia) yang Diberikan-Nya kepadamu. Sesungguhnya Tuhan-mu sangat cepat Memberi hukuman dan sungguh, Dia Maha Pengampun, Maha Penyayang" (Q.S AlAn am, / 6: 165).

Bisnis dalam Al-Qur'an dijelaskan melalui kata tijarah, yang mencakup dua makna, yaitu: pertama, perniagaan secara umum yang mencakup perniagaan antara manusia dengan Allah. Ketika seseorang memilih petunjuk dari Allah, mencintai Allah dan Rasul-Nya, berjuang di jalan-Nya dengan harta, jiwa, membaca kitab Allah, mendirikan Shalat menafkahkan sebagian rezekinya, maka itu adalah sebaik-baik perniagaan antara manusia dengan Allah. (Bakhri \& Purnama, 2018) Dalam salah satu ayat Al-Qur'an dijelaskan bahwa ketika seseorang membeli petunjuk Allah dengan kesesatan, maka ia termasuk seorang yang tidak beruntung.
Adapun makna kata tijarah yang kedua adalah perniagaan secara khusus, yang berarti perdagangan ataupun jual beli antar manusia. Beberapa ayat yang menerangkan tentang bagaimana bertransaksi yang adil di antara manusia terangkum dalam al-Baqarah (2):282; an-Nisa(4):29, dan an-Nur(24):37. Pada surat al-Baqarah disebutkan tentang etika dan tata cara jual beli, utang piutang, sewa menyewa, dan transaksi lainnya. Ayat ini pula yang dijadikan pedoman kegiatan akuntansi (kewajiban untuk mencatat transaksi) dan notariat (kewajiban adanya persaksian dalam transaksi) dalam pembahasan tentang ekonomi dan bisnis Islam. Sehingga diharapkan adanya suatu perniagaan adil dan saling menguntungkan antara satu pihak dengan pihak yang lain, seperti yang tertera dalam surat an-nisa. Dan motif dari suatu perniagaan hendaknya untuk beribadah, karena dalam surat an-nur disebutkan bahwa seseorang ketika sedang bertransaksi hendaklah selalu mengingat Allah, menegakkan shalat, dan membayar zakat. Jadi, perniagaan dalam arti yang lebih khusus pun tidak akan pernah luput dari aktivitas untuk mengingat Allah. Sehingga diharapkan hal ini bisa menjadi suatu kontrol bagi seseorang peniaga dan pengusaha, agar selalu berbuat kebaikan dan menjauhi perilaku yang merugikan dalam suatu aktivitas bisnis. (Prasetyo, Agustina, \& Wijij, 2016) 


\section{HASIL PENELITIAN}

Dalam penelitian ini, peneliti menemukan jawaban-jawaban dari para narasumber tentang bagaimana etika bisnis syariah berjalan dikalangan para pedagang di Pasar Leuwiliang. Jawaban yang didapat dari narasumber tentang etika bisnis syariah merupakan fokus penelitian yang dilakukan peneliti. Dalam penelitian ini menjelaskan bagaimana realita bisnis sehari-hari dan implementasi etika bisnis syariah di kalangan pedagang Pasar Leuwiliang. Sebagai kewajiban seorang muslim dalam hal ini merupakan pedagang adalah untuk menerapkan etika bisnis secara syariah. Berdasarkan hasil wawancara mengenai realita etika bisnis mereka sehari-hari, dan bagaimana mereka memperhatikan etika bisnis secara syariah, para pedangan memberikan tanggapan dan hambatan yang mereka lakukan dalam melakukan implementasi tersebut.

Narasumber pertama adalah dari pedagang sayuran dengan Bapak Mardial sebagai pelaku usahanya. Bapak mardial tinggal di Kampung Dukuh Galuga dan sebelumnya ia tinggal di Jakarta. Warung ini sudah berdiri sejak 2008, namun sudah membuka usaha di tempat lain sejak 2005. Bapak Mardial menceritakan bagaimana realita bisnis yang ia alami sejak membuka usaha ini dan menjawab pertanyaan yang penulis berikan terkait etika bisnis syariah.
"Saya sudah memulai usaha di sini sejak 2008, untuk perizinannya sendiri saya membayar kepada preman yang memengang daerah disini karena saya kan berjualannya lapak ya bukan ruko, ya pokoknya asal ada lahan langsung deh saya tempati. Saya memilih berdagang disini karena dekat dengan tempat tinggal saya dan disini ramai penduduknya jadi saya tertarik berjualan disini. Prinsip-prinsip etika bisnis syariah yang saya ketahui ya jujur, jangan bohong soal harga, dan tidak mempermainkan timbangan, dan prinsip-prinsip itu saya terapkan agar usaha saya berkah. Untuk menjaga kehalalan produk ya saya sayurnya beli sama yang Muslim, ya pokoknya sayur kan gabisa bohong ya halal haramnya. Untuk harga sendiri kalo saya sih tergantung harga pasar ya, untuk pelanggan juga biasanya saya kasih harga yang beda juga. Untuk menjaga kepercayaan pembeli dan pelanggan ya saya kasih barang bagus, jujur dan murah senyum itu ajasih. Dan un tuk karyawan pasti saya kasih waktu untuk shalat, walaupun kadang kalo lagi rame shalatnya ga tepat waktu. Kalo zakat sih saya belum, tapi kalo infaq sama shodaqoh alhamdulillah hampir setiap hari, kalo ada yg minta-minta gitu ya saya kasih, kalo gaada ya engga ngasih."

Narasumber kedua adalah dari pedagang Emas \& Perak, dengan Bapak Zulfikar sebagai pelaku usahanya. Bapak Zulfikar tinggal di Leuwiliang. Toko ini sudah berdiri 
sejak 12 Februari 2018. Bapak Zulfikar menceritakan bagaimana realita bisnis yang ia alami sejak membuka usaha ini dan menjawab pertanyaan yang penulis berikan terkait etika bisnis syariah.

"saya sudah memulai usaha emas \& perak sejak 2014, untuk perizinannya sendiri sudah saya lengkapi dengan SIUP dan SKHU. Saya berjualan disini karena tinggal di daerah Leuwiliang dan saya berfikir tempat ini dekat dan juga srategis. Prinsip-prinsip etika bisnis secara syariah yang saya ketahui itu jujur, amanah dan menjaga kepercayaan pembeli, dan untuk implementasinya sendiri sudah saya terapkan sejak di bukanya toko ini dan di tanamkan kepada karyawankaryawan saya. Untuk menjaga kehalalan produk atau bisa disebut kwalitas ya saya selalu jujur dengan timbangan dan juga menggunakan bahan baku yang bagus. Untuk menetapkan harga sendiri, saya mengikuti harga pasar saja karena kalo emas kan memang seperti itu penetapan harganya. Dan cara saya untuk menjaga kepercayaan pembeli \& pelanggan adalah dengan terbuka dengan kejelasan produk yang saya jual seperti kondisinya bagus atau cacat, atau timbangan, atau campurannya, pokoknya seperti itu saja. Lalu juga saya berusaha agar toko saya selalu lengkap barangnya, agar jenis emas atau perak yang di inginkan pembeli tersedia disini dan juga saya memperhatikan pelayanan yang baik, karna saya percaya jika pelayanan yang saya berikan itu baik, maka mereka akan senang dan kembali membeli kesini. Untuk toleransi beribadah, saya memberikab waktu kurang lebih 30 menit, karena biasanya perempuan itu butuh waktu lebih lama pada saat istirahat shalat daripada istirahat makan siang hehe. Untuk Zakat, Infaq ataupun shadaqah, skema nya adalah 2,5\% dari laba per tahun, dan untuk Infaq dan Shadaqah itu hampir setiap hari, karena di pasaar banyak pengamen, proposal kegiatan dan lain sebagainya, jadi kami anggap itu sebagai infaq dan shodaqoh.

Narasumber ketiga adalah dari pedagang pakaian, dengan Bapak Ahmad Yani sebagai pelaku usahanya. Bapak Ahmad Yani tinggal di Leuwiliang tepatnya di Kampung Lebak Sirna. Toko ini sudah berdiri sejak 2007. Bapak Ahmad Yani menceritakan bagaimana realita bisnis yang ia alami sejak membuka usaha ini dan menjawab pertanyaan yang penulis berikan terkait etika bisnis syariah.

“ 2007 itu saya sudah mulai berjualan pakaian, karena waktu itu pakaian sangat besar peminatnya dan belum banyak toko pakaian disini saat itu. Untuk perizinannya saya mengurus SKHU ke kecamatan. Saya tinggal di daerah Leuwiliang. Prinsip-prinsip etika bisnis syariah yang saya ketahui adalah jujur, dan rukun-rukun jual beli . Untuk penerapannya sendiri dari awal toko ini saya 
buka, saya memang ingin menerapkan konsep syariah agar berkah usaha yang saya jalankan dan tidak melanggar syariat islam. Untuk memastikan Kehalalan atau kwalitas produk yang saya jual dalah dengan memilih distributor yang muslim atau satu keyakinan, lalu menyimpan produk di gudang dengan rapi dan memastikan gudang itu bersih agar tidak ada tikus yang masuk dan merusak dagangan saya. Penetapan harga yang saya lakukan dengan cara Harga Modal + Margin lalu jika ada tawar menawar saya akan pastikan harga yang di tawar tidak kurang dari perhitungan tersebut. Mejaga kepercayaan pembeli dan lagganan biasanya saya memastikan produk saya bagus, rapih, bersih, dan lengkap. Waktu shalat biasanya saya berikan 30 menit. Untuk transaksi zakat, infaq, shadaqah, saya menjalankan ketiganya namun bedanya untuk zakat skalanya setiap tahun dan infaq shadaqah hampir setiap hari."

Narasumber keempat adalah dari pedagang daging, dengan Ibu Eneng sebagai pelaku usahanya. Ibu eneng tinggal di Cibatok. Toko ini sudah berdiri sejak 2003. Ibu eneng menceritakan bagaimana realita bisnis yang ia alami sejak membuka usaha ini dan menjawab pertanyaan yang penulis berikan terkait etika bisnis syariah.

"Nama saya ibu Eneng, saya dari Cibatok. Kalau buka usaha di sini sudah sejak 2000. Buka di sini ga susah mba, izinnya mudah saja, hanya membayar iyuran ke ketua pasar. Saya berjualan disini karena ini usaha ibu saya sebelumnya, saya hanya melanjutkan usaha yang sudah beliau jalani, disamping itu rekan-rekan saya pun berjualan di sini, jadi enak banyak teman. Untuk prinsip-prinsip etika bisnis syariah yang saya pegang sampai saat ini adalah kwalitas dan ke halalan dagangan mba, itu sudah menjadi hal nomor satu yang saya perhatikan, Untuk kehalalan produk saya kebetulan berternak sendiri, jadi kwalitas dan ke halalan produk sudah saya jamin. Kalau penetapan harga saya mengikuti harga pasar saja. untuk menjaga kepercayaan pembeli, saya selalu memberikan daging yang segar dan berkualitas, saya yakin jika pembeli saat ini sudah cukup pintar dalam memilih barang dagangan yang saya jajakan. Saya selalu memberikan toleransi untuk beribadah, karena iu sudah kewajiban umat muslim. Untuk zakat, saya belum menunaikan. Tetapi untuk infaq dan shadaqoh inshaallah sudah saya tunaikan saat ada yang membutuhkan seperti pengemis, pengamen, dsb."

Wawancara yang terakhir dilakukan kepada Bapak Azmi Reza. Beliau adalah pemilik kios makanan ringan. Bapak reza tinggal di Cemplang. Toko ini sudah berdiri sejak tahun 2000. Bapak Azmi menceritakan bagaimana realita bisnis yang ia alami sejak membuka usaha ini dan menjawab 
pertanyaan yang penulis berikan terkait etika bisnis syariah.

"saya memulai berjualan sejak tahun 2007 tetapi usaha ini sebelumya sudah di jalankan oleh ibu saya sejak tahun 2000. Untuk izinnya sendiri saya hanya membayar kepada kepala pasar. Saya berdagang disini karena melanjutkan usaha ibu saya saja. secara pribadi saya tidak begitu mengetahui prinsipprinsip etika bisnis secara syariah, tetapi jika mba bertanya bagaimana saya menjual produk dagangan saya, saya selalu menjaga kehalalan produk yang saya jual, soalnya itu penting sekali menurut saya. Karena konsumen saya kan kebanyakan muslim, jadi saya harus memastikan produk yang saya jual itu halalan toyyiban. Untuk penetapan harga saya mengikuti harga pasar saja, terkadang saya membandingan harga dengan penjual yang lain agar bisa menjual lebih murah dari saingan saya. Menjaga kepercayaan pelanggan dengan memberikan dagangan dengan kondisi yang baik serta pelayanan yang ramah agar pembeli senang untuk membeli dagangan saya kembali. Toleransi waktu untuk Shalat selalu saya berikan kepada karyawan, walaupun terkadang tidak tepat waktu tetapi pasti saya berikan waktu untuk beribadah. Infaq dan shodaqoh inshaallah sudah di tunaikan, karena di pasar setiap hari selalu ada pengemis atau proposal keliling. Kalau zakat jujur saya belum menjalankan, karena saya rasa saya belum berhak untuk berzakat."

\section{SIMPULAN}

Berdasarkan hasil penelitian dan pembahasan yang telah dilakukan, maka dapat ditarik beberapa kesimpulan penelitian sebagai berikut:

Dalam penelitian yang dilakukan, pada faktanya realita bisnis sehari-hari para pedagang di Pasar Leuwiliang sudah sedikitnya menerapkan praktik etika bisnis syariah, namun belum semuanya benar-benar faham mengenai apa saja etika bisnis syariah.

Hasil penelitian yang dilakukan menunjukkan bahwa pengetahuan agama yang dimiliki oleh pedagang telah diterapkan dalam kegiatan bisnisnya. Mereka menjalankan bisnis dengan tetap memakai aturan yang di perbolehkan oleh ajaran agama. Masih ada sedikit hal yang melenceng dari agama islam. Pemahaman mereka tentang bisnis yang baik sesuai dengan etika bisnis syariah sesuai dengan indikator penulis dapat dilihat dari pertanyaan yang diajukan peneliti yaitu : Kejujuran dalam menjual barang, Produk yang dijual belikan halal, Kesatuan (tauhid) dengan tetap menjaga ibadah wajib setiap berbisnis, Keseimbangan (keadilan) dilihat saat mereka meratakan harga dengan harga pasaran, Cara mereka melayani pembeli dengan ramah.

Hasil presentasi wawancara yang dilakukan oleh peneliti mendapatkan hasil 
bahwa $40 \%$ responden atau 10 dari 25 responden masih belum memehami konsep etika bisnis syariah. (khidmah)

\section{DAFTAR PUSTAKA}

Amalia, F. (014). Etika Bisnis Islam: Konsep dan Implementasi pada Pelaku Usaha Kecil. Al-Iqtishad: Jurnal Ilmu Ekonomi Syariah 6.1, 133-142.

Azizaturrohmah, S. N., \& Mawardi, I. (2015). Pemahaman Etika Berdagang Pada Pedagang Muslim Pasar Wonokromo Surabaya (Studi Kasus Pedagang Buah). Jurnal Ekonomi Syariah Teori dan Terapan 1.4.

Baidowi, A. (2016). Etika Bisnis Perspektif Islam. Jurnal Hukum Islam.

Bakhri, S., \& Purnama, L. (2018). TINJAUAN ETIKA BISNIS ISLAM DALAM STRATEGI PEMASARAN HOME INDUSTRI TAHU SARI RASA. Al-Mustashfa: Jurnal Penelitian Hukum Ekonomi Syariah 3.2, 282-299.

Bayuni, E. M., \& Srisusilawati, P. (2018). KONTRIBUSI INSTRUMEN MONETER SYARIAH TERHADAP PENGENDALIAN INFLASI DI INDONESIA. AMWALUNA: Jurnal Ekonomi dan Keuangan Syariah 2.1, 18-38.

Firmansyah, A. F. (2013). "Praktik Etika Bisnis Islam (Studi Kasus Pada Toko Santri Syari'ah Surakarta). Yogyakarta: UIN Sunan Kalijaga Yogyakarta.
Gunawan, A. (016). Analisis Pengaruh Etika Kerja Islam Terhadap Komitmen Organisasi Dengan Komitmen Profesi Sebagai Variabel Intervening (Studi Empiris Terhadap Internal Auditor Bank Di Jawa Tengah). Economica: Jurnal Ekonomi Islam 1.2, 93-108.

Juliyani, E. (2016). Etika Bisnis dalam Perspektif Islam. Jurnal Ummul Qura 7.1.

Mabarroh, a. (2016). Etika Perilaku Periklanan dalam Bisnis Islam. JESI (Jurnal Ekonomi Syariah Indonesia) 3.1, 37-48.

Prasetyo, T., Agustina, Y., \& Wijij, t. (2016). Bisnis Syariah: Etika Islam dan Instrumen Keuangan Syariah Sebuah Pendekatan Meta Analisis." Ekonomi Syariah Dalam Pemberdayaan Sektor Riil Di Indonesia.

Rosiyana, L., Arifin, Z., \& sunarti. (017). IMPLEMENTASI ETIKA BISNIS ISLAM GUNA MEMBANGUN BISNIS YANG ISLAMI (Studi pada Waroeng Steak And Shake Cabang Malang). Jurnal Administrasi Bisnis 53.1, 196-201.

Saifullah, M. (2011). "Etika bisnis Islami dalam praktek bisnis Rasulullah. Walisongo: Jurnal Penelitian Sosial Keagamaan 19.1, 127-156.

Saman, M. (2010). Persaingan Industri PT. Pancanata Centralindo (Perspektif Etika Bisnis dalam islam. Uin Syarif Hidayatullah. 
Suprayitno, E. (2008). Ekonomi mikro:

Perspektif Islam. UIN-Maliki Press.

Syihabuddin, A. (2017). Etika Distribusi

Dalam Ekonomi Islam. Al-Qanun:

Jurnal Pemikiran dan

Pembaharuan Hukum Islam 20.1, 77-103. 
Ira Puspitasari , Analisis Praktik Etika Bisnis Islam 